\title{
Prevalence of Snail Vectors of Schistosomiasis in the Kpong Head Pond, Ghana
}

\author{
D. R. Yirenya-Tawiah*, A. Abdul Rashid', G Futagbi', I. Aboagye' and M. Dade' \\ Volta Basin Research Project (VBRP)/Department of Animal Biology and Conservation \\ Science, University of Ghana, Legon \\ 'Department of Animal Biology and Conservation Science, 'Volta River Authority, Akosombo, \\ Ghana \\ *Correspondingauthor; E-mail:dzidzoy@ug.edu.gh ordzidzoy@hotmail.com
}

\begin{abstract}
Schistosomiasis, a parasitic disease caused by the blood fluke Schistosoma sp. became a serious public health problem in Ghana after the Volta River was dammed in Akosombo in 1964. The formation of the Kpong head pond, about $25 \mathrm{~km}$ below the Akosombo dam, as a result of a second dam built at Kpong became an active schistosomiasis transmission site. The Volta River Authority (VRA) recently began an initiative of combining manual clearing of aquatic vegetation with chemotherapy as a way of managing the disease. However, no scientific monitoring of the effect of aquatic weed clearing on the vector population is being conducted. The study was initiated in the Kpong head pond to provide baseline data for subsequent monitoring and impact assessment of the initiative. It involved sampling of the banks of the head pond for aquatic snails at six different sampling sites of $1 \mathrm{~m}$ each, chosen at $100 \mathrm{~m}$ interval along the shoreline. Physicochemical factors which affect aquatic snail population were also determined. Aquatic snails sampled were Bulinus truncatus, Bulinus globosus, Biomphalaria pfeifferi, Melanoides spp, Physa waterlotti and Pila sp. where the first three are intermediate host of the schistosoma parasite. The study revealed $B$. truncates as the most frequent occurring vector $(71.0 \%)$, followed by Biomphalaria $(12.0 \%)$ and $B$. globosus $(6.1 \%)$ The mean numbers of vector snails sampled per $\mathrm{m}^{2}$ were $B$. Truncates $61 / \mathrm{m}^{2}$, B. globosus $5 / \mathrm{m}^{2}$, and $B$. pfeifferi $11 / \mathrm{m}^{2}$. The presence of aquatic weeds and favourable physicochemical conditions of the water were found to provide a conducive environment for the vectors to thrive and hence sustain schistosomiasis transmission in the head pond. It is, therefore, recommended that a 5 -year period of studies be undertaken to assess the impact of manual clearing of aquatic weeds on the snail population.
\end{abstract}

\section{Introduction}

Schistosomes (blood flukes) are digenetic trematodes of the super family Schistosomatoidea. They cause the disease schistosomiasis, which is commonly called bilharziasis. The parasites undergo part of their developmental phase into infective forms in water borne planorbid snails. Hence, schistosomiasis is a helminthic water-borne disease. Five species of Schistosoma have been found to be pathogenic parasites of man (Ross et al., 2007; Gryseels et al., 2006). These are; Schistosoma haemato-bium, causing urinary schistosomiasis, S. mansoni,
S. japonicum, S. mekongi and $S$. intercalatum, all causing intestinal schistosomiasis.

Human schistosomiasis remains one of the most important parasitic diseases in the tropics for which there are yet to be vaccines. About 200 million people are estimated to be infected and 500-600 million more exposed to infection (Webbe, 1981) and about 131 million infected in Sub-Saharan Africa alone. The disease is endemic in Ghana and its public health importance was reported by McCullough (1954), who noted then that approximately $20 \%$ of the total population of 
Ghana suffered from urinary schistosomiasis at sometime in their lives. The parasites responsible for the disease in Ghana are mainly $S$. haematobium and S. mansoni (Bosompemetal., 2004).

The Schistosoma parasite undergoes part of its development in fresh water planorbid snails, which serve as intermediate hosts. These planorbid snails usually attach themselves to aquatic vegetation which serves as food, microhabitats and protects them from being washed away by moving water currents. They are also used by the snail vectors as repository for their eggs (Ofori, 1999). These intermediate host snails occur in ponds, dams, lakes, slow sections of streams, drains and irrigation canals, marshes and swamps (Obeng, 1997). Various genera of these planorbid snails have been associated with specific parasite types. For example Bulinus sp. is responsible for hosting the Schistosoma haematobium parasite and Biomphalaria, and Oncome-lania sp. responsible for hosting $S$. mansoni and $S$. japonicum, respectively (Ayanda, 2009; Madsen et al., 2008).

Human activity along the Kpong head pond is very intense. It is common to find people bathing, washing, fish mongering and fishing there. A recent study accessed the prevalence among adults in the study area as 32.4\% (Dade et al., 2010 unpublished). Manual clearing of aquatic vegetation has been proposed as controlling the vector population at transmission sites. The Volta River Authority (VRA) recently contracted locals to engage in periodic clearing of aquatic weeds at water contact sites. However, no scientific studies are ongoing to assess the effect of this activity on vector population. The study was, therefore, conducted to provide a baseline data of the prevalence of schistosome vector snails at transmission sites in the head pond.

\section{Material and methods}

Study area

The study was conducted in Ayikpala, a suburb of Kpong. Kpong is a typical commercial town located about $70 \mathrm{~km}$ east of Tema. Ayikpala is about $50 \mathrm{~m}$ from the head pond. Majority of people living along the banks are mainly fisher folks, who have migrated from the lower Volta Basin to fish in the head pond soon after creation. The water from the head pond serves as an important resource for domestic water supply, occupation, transport and recreation.

\section{Sampling sites}

Six sampling sites were chosen and numbered at $100 \mathrm{~m}$ interval from one end of the bank to the other. The geographical locations of all sampling sites were taken with geographical position satellite, model GARMIN GPS 72 and tape measure. The coordinates of the site are N-06 $09^{\prime} / 31.4^{\prime \prime}, \mathrm{E}-$ 003'00'52.4". The sites were, therefore, chosen to cover areas of human activity.

\section{Sampling procedure}

Data was collected between January and March 2007. All samplings were undertaken twice in one month so as to get a average value of the parameters taken at the various sites.

\section{Snail sampling}

At each sampling point, a 1-m² quadrant was demarcated along human contact sites. 
Snail sampling was done within the quadrant using a scooping net with a long handle. All the debris and aquatic weeds collected were kept in labelled ice chest which corresponded with the site number. The samples were then taken to the laboratory at the Department of Animal Biology and Conservation Science (ABCS) and sorted out with the aid of a magnifying glass and forceps. Aquatic weeds associated with the vector snails were collected and identified in Department of Botany, University of Ghana.

\section{Water quality assessment}

Physical parameters. The physical parameters taken include temperature, flow rate, salinity, $p \mathrm{H}$, conductivity, transparency and water depth. For these parameters, the water quality checker was immersed into the sampled $1 \mathrm{~m}^{2}$ areas and this gave the temperature, salinity, conductivity, and $p \mathrm{H}$ readings. The transparency was measured using a secchi disk, and water depth measured with a calibrated PVC pipe. The rate of flow was determined according to the method described by Schwoerbel (1970).

Chemical parameters. Water samples within the sampled area were collected into sterilised 1-litre bottles and kept in an ice chest at about $4{ }^{\circ} \mathrm{C}$ and transported to the laboratory where the analysis was done. The cadmium reduction method (Pillows or AccuVae Ampuls) was used to determine the nitrate level in the water. The orthophosphate PhosVer 3 (Ascorbic acid) method was used to determine the phosphate level of the water. The SulfaVer4 method (Powder Pillow AccuVac Ampuls) was also used to determine the sulphate level of the water, and the resulting data was tabulated as the site and the level of the corresponding chemical parameter.

\section{Results}

\section{Snail collections}

A total of 1034 snails were collected throughout the study period. Five different snail species were identified. These were Bulinus truncatus, B. globosus, Biomphalaria pfeifferi, Melanoides sp., Physa waterlotti and Pila sp. The dominant schistosome vector species found were the $B$. truncates $735 / 1034$ (71.0\%), followed by Biomphalaria 125/1034 (12.0\%) and B. globosus (6,1\%) (Fig. 1). The average number of $B$. truncates collected was 62 per $\mathrm{m}^{2}$ and $B$. pfeifferi, 11 per $\mathrm{m}^{2}$. The aquatic plants identified along the banks were Commelina congesta, Typha spp., Cyperus spp., Pistia stratiotes and Ceratophyllum demersum.

\section{Physico-chemical parameters}

Table 1 summarises physico-chemical parameters determined by the study. The mean depth at which physico-chemical parameters were taken was $114.58 \mathrm{~cm}$, and the mean water temperature found by this study was 30.3 C. The water temperature was found to range between $27.4-33{ }^{\circ} \mathrm{C}$, while conductivity ranged between 0.122 0.07 . The water was slightly acidic with a mean $p \mathrm{H}$ of 6.4. As expected salinity was zero at all the sites. Transparency at each site was clear to the bottom except at sites 5 and 6 , which showed transparencies of $10 \mathrm{~cm}$ and $120 \mathrm{~cm}$, respectively. The flow rate determined between $0-2 \mathrm{~cm} / \mathrm{s}$.

The chemical analysis, on the other hand, showed appreciable levels of phosphate, nitrate, and sulphate in the water. Phosphate levels ranged between $0.08-0.24 \mathrm{mgl}^{-1}$ with site 6 recording the highest of $0.24 \mathrm{mgl}^{-1}$ and site 4 recorded the lowest value of $0.08 \mathrm{mgl}^{-1}$. 


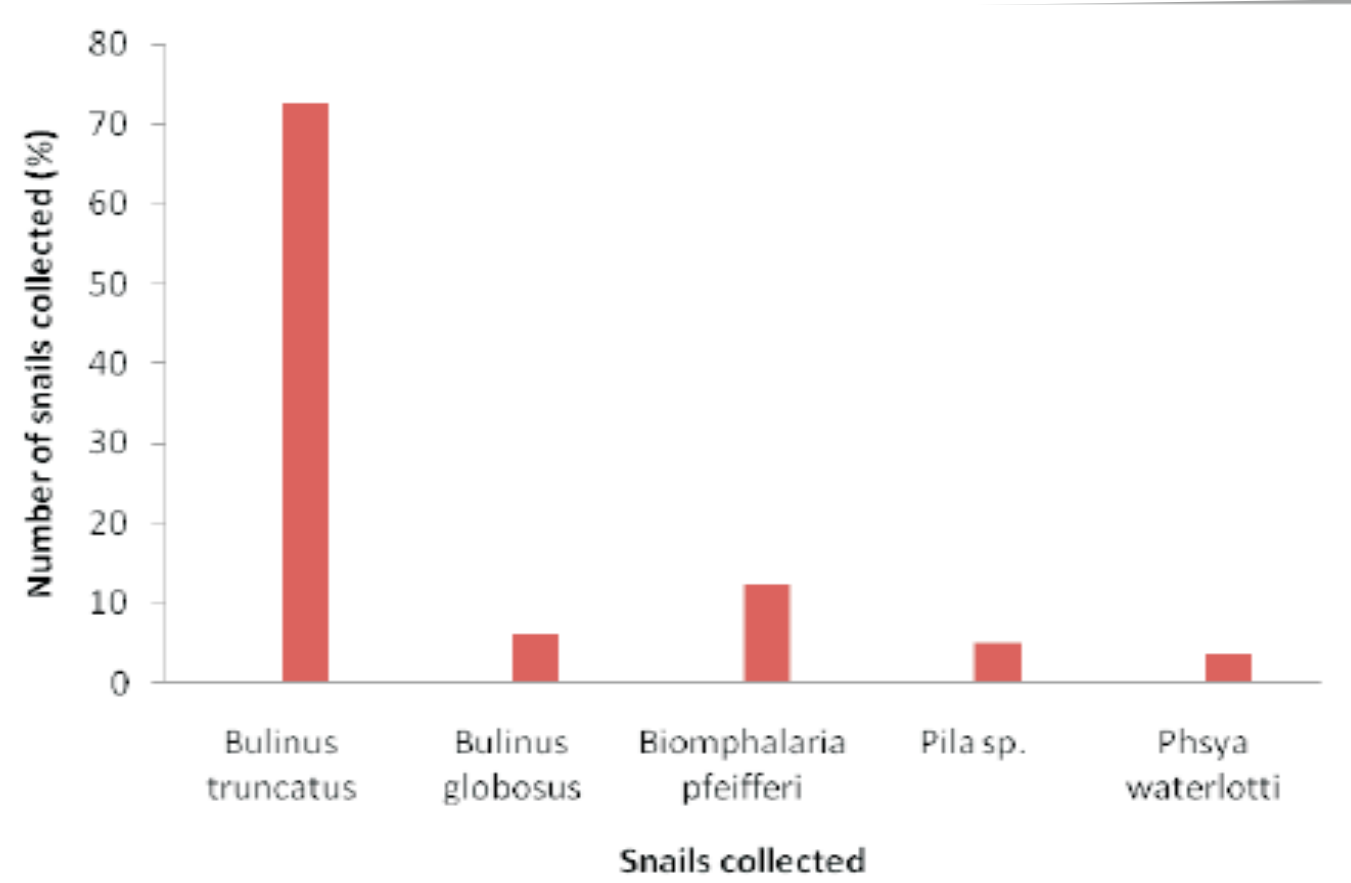

Fig. 1. The relative percentage of the snails collected in the Kpong head pond during the study

TABLE 1

Levels of physico-chemical parameters determined in the Kpong head pond during the study period

\begin{tabular}{lcc}
\hline Physical parameters & Mean & Values \\
& 30.3 & Range \\
\hline Temperature $\left({ }^{\circ} \mathrm{C}\right)$ & 0.099 & $27.4-33.0$ \\
Conductivity $\left(\mu \mathrm{Scm}^{+}\right.$ & 6.4 & $0.07-0.122$ \\
$p \mathrm{H}$ & 0 & $6.2-6.4$ \\
Salinity & 114.58 & 0 \\
Depth $(\mathrm{cm})$ & 15 & $31-246$ \\
Transparency $(\mathrm{cm})$ & & $10-120$ \\
& 0.16 & \\
Chemical parameters & 1.15 & $0.08-0.24$ \\
Phosphate $\left(\mathrm{mgl} \mathrm{l}^{\prime}\right)$ & 1.9 & $0.9-1.4$ \\
Nitrate $\left(\mathrm{mgl} \mathrm{l}^{-}\right.$ & 4.6 & $0.0-6.0$ \\
Sulphate $\left(\mathrm{mgl} \mathrm{l}^{\prime}\right)$ & & $0.9-7.3$ \\
Dissolved oxygen $\left(\mathrm{mgl}{ }^{\prime}\right)$ & & \\
\hline
\end{tabular}


The nitrate level also varied between 0.9 $\mathrm{mgl}^{-1} \mathrm{H}$ and $1.4 \mathrm{mgl}^{-1} \mathrm{H}$. The sulphate level showed quite some interesting variations. The highest level of $6.0 \mathrm{mgl}^{-}$was recorded in site 4 and the lowest level of $0.0 \mathrm{mgl}^{-1}$ in site 5 .

\section{Discussion}

Six different species of snails were collected from the study area of which three were vectors of the Schistosoma parasite. Bulinus truncatus was the most dominant vector species found and this was not suprising as it is often found in large water bodies such as lakes while $B$. globosus is confined to small streams in Ghana (Chu et al., 1978). The Kpong head pond is a lake system that was created just below the Kpong dam. The high occurrence of B. trunctus found by this study, coupled with the intense human activity that occurs at the banks of the head pond, indicates that an active transmission of $S$. haematobium parasite occurs in the area. The snails were commonly found attached to identified water weeds, especially, Ceratophylum derme-sum, and also sometimes found attached to surfaces of submerged sufaces such as dead logs and other junks in the water.

Temperature influences the distribution and the density of aquatic snails, and the rate of schistosomal development in the snail host, and probably influences the distribution of schistosomiasis (Appleton, 1978; Sturrock, 1993). Schistosomiasis has been reported to occur over areas with a temperature range of $20-35{ }^{\circ} \mathrm{C}$ (Oliver \& Ansari, 1967), flourishing best at constant and warm temperatures. Species of Lymnaedae, Physidae, and Planorbidae have been reared through several generations at about $35{ }^{\circ} \mathrm{C}$ (Harman \& Berg, 1971). A temperature range of $27.4-33{ }^{\circ} \mathrm{C}$ was recorded in the Kpong waters during the study, and this appears to be favourable to the aquatic snails, as there were no climatic changes in temperature throughout the study.

Low $p \mathrm{H}$ value may be harmful to snail vectors of schistosomiasis, as they result in the coagulation of the mucus on exposed skin surfaces (Jordan \& Webbe, 1982). A $p \mathrm{H}$ range of $6.2-7.2$ on the other hand, is favourable for most intermediate snail hosts (Alves, 1958). This study recorded a mean $p \mathrm{H}$ 6.4. Generally, this $p \mathrm{H}$ level is very conducive for snail vector development. Jordan \& Webbe (1982) found extreme acidic water body to result in low Biomphalaria spp. populations and in some cases, total absence of snails may be observed. The slightly acidic water in the head pond which may be due to low levels of free $\mathrm{CO}_{2}$, on the other hand, supports the growth of the aquatic snails.

The study was conducted in the dry season where water movements are expected to be low and offering a stable environment for snails to lodge onto surfaces and not being washed away (WHO, 1965).. Rainfall affects water movements and temperature, thereby, affecting the distribution and density of the aquatic snails and the rate of schistosomal development in the snail host (Appleton, 1978; Sturrock, 1993). Snail intermediate host are intolerant of strong currents, and breeding colonies are not found in swift flowing streams or water bodies; they are usually found in areas where the velocity of flow is below $40 \mathrm{~cm} / \mathrm{s}$ (Jones, 1993).

When the velocity is extremely high, as in rivers and streams, the snails are unable to relax hold in the slightest degree and, therefore, cannot move or feed and can no 
longer maintain themselves (WHO, 1965). The work of Laamrani et al. (2000) has shown that increasing water velocity beyond $40 \mathrm{~cm} / \mathrm{s} \mathrm{kept} \mathrm{Bulinus} \mathrm{truncatus} \mathrm{density} \mathrm{low.} \mathrm{A}$ flow rate, ranging between $0-2 \mathrm{~cm} / \mathrm{s}$ observed in this study, is far below the critical value recorded by Jones (1993). This period of data collection, therefore, signifies the period when snail densities are expected to be high.

The snails for their metabolic activities (WHO, 1965) need oxygen. The study recorded a mean dissolved oxygen of $4.6 \mathrm{mgl}$ . This finding is in consonance with other findings that the desired concentration of dissolved oxygen for intermediate host is 0.40-16.00 mg/l (Harman \& Berg, 1971). This suggests that the amount of dissolved oxygen in the water is favourable for the snail host. This range of oxygen dissolved in the water was probably due to the oxygen produced by aquatic plants by photosynthesis.

Conditions such as high silt load prevent the establishment of aquatic weeds (Ofori, 1999). The transparency of the water taken in the study showed that the first, second, third, and fourth sites were all clear to the bottom whilst sites five and six showed transparencies of 70 and $120 \mathrm{~cm}$, respectively. The transparency facilitates the penetration of sunlight to the bottom, particularly in the littoral zone, encouraging the establishment and proliferation of aquatic weeds (Ofori, 1999), which promotes the growth and survival of the snail vectors.

The salinity recorded at all the sites was zero, which is normal for a fresh water system not directly connected to an ocean. Snail vectors, especially those infected with the parasite survive stressfully high temperatures and low salinity better than uninfected ones (Riel, 1975). The mean conductivity recorded was $0.09 \mu \mathrm{Scm}^{-}$and this was well within the WHO (1965) range of $0.02-0.30 \mu \mathrm{Scm}$ for fresh water systems, which support the growth of fresh water fauna and, therefore, making the head pond a good habitat for the snail intermediate host.

The phosphate, sulphate, and nitrate levels showed little variation in all the sites. These play an indirect role of supporting the proper growth of the aquatic plants. As these plants boom, they provide enough food and shelter for the intermediate host snail and, therefore, increase their density in the head pond.

Overall, the physico-chemical conditions prevailing in the head pond are favourable, and vector snails will continue to flourish so long as these factors prevail. Nevertheless, the ongoing manual clearing of aquatic vegetation along the banks of the river may disturb this equilibrium and invariably affect snail population. It will be recommended that the study must be conducted in the rainy season to provide a information on snail densities in that season as well. Manual clearing of aquatic weed in the head pond must, however, be continued and snail vector densities monitored for about 5 years so as to provide data for impact assessment of manual clearing on schistosome snail density.

\section{Acknowledgement}

The authors acknowledge the contributions of Mr E. Ansah, Mr D Bentum and Mr Akosa of the Volta Basin Research Project, and Mr J. Otchere of Noguchi Memorial Institute of Medical Research. 


\section{References}

Alves W. (1958). Chemical constituents of surface waters in southern Rhodesia with reference to the molluscan vectors of Bilharziasis. Bull. Wld Hlth Org. 18(5): 1071.

Appleton C. C. (1978). Review of literature on biotic factors that influence the distribution and life cycles of bilharziasis intermediate host snails. Malacol. Rev. 11: 1-25.

Ayanda O. I (2009). Prevalence of snail vectors of schistosomiasis and their infection rates in two localities within Ahmadu Bello University (A.B.U.) Campus, Zaria, Kaduna State, Nigeria. J. Cell Anim. Biol. 3(4): 058-061.

Bosompem K. M., Bentum I. A., Otchere J., Anyan W. K., Brown C.A., Osada Y., Takeo S., kojima S. and Ohta N. (2004). Infant schistosomiasis in Ghana: a survey in an irrigation community. Trop. Med. int. Hlth 9 (8): 917-922.

Chu K.Y., Kpo H. K. and Klumpp R. K (1978). Mixing of Schistosoma haematobium strains in Ghana. Bull. Wld Hlth Org. 56 (4): 601-608.

Gryseels B., Polman K., Clerinx J., and Kestens L. (2006). Human schistosomiasis. Lancet 368: 1106-1118.

Harman W. N. and Berg C. O. (1971). The freshwater Gastropoda of central New York with illustrated keys to the genera and species. Search: Cornell Univ. agric. exp. St. 1: 1-68.

Jones H. R. R. (1993). Water velocity as a control of aquatic snails in concrete canal systems for irrigation. (PhD Dissertation.) Loughborough University of Technology, United Kingdom.

Jordan P. and Webbe G. (1982). Schistosomiasis: Epidemiology, Treatment, and Control. Heinemann Publication. William Heinemann Medical Books Ltd, London. pp. 300-361.

Laamrani H., Khalaayoune K., Boelee E., Laghrougi M. M., Madson H. and Gryseels B. (2000). Evaluation of environment to control snails in an irrigation system in Central Morocco. Trop.Med. int. Hlth 5(8): 545-552.

Madsen H., Carabin H., Balolong, D. Tallo V. L.,
Olveda R., Yuan M. and McGarvey S. T. (2008). Prevalence of Schistosoma japonicum infection of Oncomelania quadrasi snail colonies in 50 irrigated and rain-fed villages of Samar Province, the Philippines. Acta Tropica 105(3): 235-41

McCullough F. S. (1954). Some aspects of the investigation of Schistosomiasis and its Snail host in the Gold Coast. In Report of proceedings of a conference of health inspectors and the health superintendents held in Accra, Gold Coast, 5th and 6th August 1954. Ghana Government Printer, Accra .pp. 53-59.

Ofori J. (1999). Water Resources Project \& Women's Health. Water Research Institute (CSIR), Accra, Ghana.

Obeng L. E. (1997). Parasites, the sly and sneaky enemies inside you. T.J Press Ltd, Padstow, Cromwell.

Oliver L. and Ansari N. (1967). The epidemiology of Bilharziasis. (F. K. Mostofi, ed.), pp. 8-14. Springer-Verlag. Berlin Heidelberg. New York.

Riel A. (1975). Effect of trematode on survival of Nassarius obsoletus (say). Proceedings of the Malacological Society, London. 41: 527-8.

Ross A. G., Vickers D., Olds G. R., Shah S. M. and McManus D. P. (2007). Katayama syndrome. Lancet Inf. Dis. 7(3): 218-224.

Schwoerbel J. (1970). Methods of Hydrobiology. Pergamon Press, Toronto, Ontario

Sturrock R. F. (1993). The intermediate host and hostparasite relationships. In Human schistosomiasis. (P. Jordan, G. Webbe and R. F. Sturrock, eds), pp. 33-85. CAB International, Wallingford.

World Health Organisation (1965). Snail control in the prevention of Bilharziasis. Report of WHO Expert Committee. Geneva: pp.11-12, 63-85, 123-128, 214.

World Health Organisation (1993). The Control of Schistosomiasis. Second Report of the WHO Experts Committee. World Health Organisation, Geneva.

Webbe G. (1981). Schistosomiasis: some advances. Br. Med. J. 283: 1-8. 